\title{
A novel approach of applying copper nanoparticles in minimum quantity lubrication for milling of Ti-6Al-4V
}

\author{
Songmei, Y. ${ }^{a, b,{ }^{*}}$, Xuebo, H. ${ }^{a, b}$, Guangyuan, Z. ${ }^{a, b}$, Amin, M. ${ }^{a, b}$ \\ ${ }^{a}$ Beihang University, School of Mechanical Engineering and Automation, Beijing, P.R. China \\ beijing Engineering Technological Research Center of High-efficient \& Green CNC Machining Process and Equipment, \\ Beijing, P.R. China
}

\section{A B S T R A C T}

Presently, nanoparticles are mixed into lubricants to enhance the lubricating and cooling properties. Some research works are available on minimum quantity lubrication (MQL) machining performance of nanofluids suspended with MoS2, Al2O3 and xGnP nanoparticles. However, the deficiency has been found in applying of metal particles like copper $(\mathrm{Cu})$ nanoparticles. In this research, nanofluids have been prepared by mixing four types of nanoparticle $(\mathrm{Cu}$, Graphite, MoS2 and Al203) into natural-77 vegetable oil with two concentrations (1\% and $2 \%)$. Taguchi's orthogonal array has used for experimental design. The machining performance of nanofluids are evaluated with regard to the reduction in cutting force and surface roughness during MQL milling of Ti-6Al-4V alloys. Analysis of variance (ANOVA) has carried out to investigate the relative influence of machining parameters. From the analysis, $\mathrm{Cu}$ and Graphite nanoparticles have shown higher effects for reducing cutting force and surface roughness. The results of ANOVA have shown that the type and concentration of nanoparticles influence the cutting force significantly. The confirmation tests have carried out and found that copper-nanofluid reduced cutting force and surface roughness by $8.84 \%$ and $14.74 \%$, respectively. Graphite-nanofluid reduced cutting force and surface roughness by $5.51 \%$ and $21.96 \%$, respectively.
\end{abstract}

(C) 2017 PEI, University of Maribor. All rights reserved.

\section{ARTICLE INFO}

Keywords:

Copper nanoparticles

Minimum quantity lubrication

(MQL)

Cutting force

Surface roughness

Analysis of variance (ANOVA)

*Corresponding author:

yuansm@buaa.edu.cn

(Songmei, Y.)

Article history:

Received 16 January 2017

Revised 7 May 2017

Accepted 12 May 2017

\section{References}

[1] Sharma, V.S., Singh, G.-R., Sørby, K. (2015). A review on minimum quantity lubrication for machining processes, Materials and Manufacturing Processes, Vol. 30, No. 8, 935-953, doi: 10.1080/10426914.2014.994759.

[2] Saidur, R., Leong, K.Y., Mohammad, H.A. (2011). A review on applications and challenges of nanofluids, Renewable and Sustainable Energy Reviews, Vol. 15, No. 3, 1646-1668, doi: 10.1016/j.rser.2010.11.035.

[3] Globočki-Lakić, G., Sredanović, B., Kramar, D., Kopač, J. (2016). Machinability of C45e steel - Application of minimum quantity lubrication and high pressure jet assisted machining techniques, Transactions of FAMENA, Vol. 40, No. 2, 45-58, doi: 10.21278/TOF.40204.

[4] Xuan, Y.-M. (2014). An overview on nanofluids and applications, SCIENTIA SINICA Technologica, Vol. 44, No. 3, 269-279, doi: 10.1360/092013-1236.

[5] Li, C., Wang, S., Zhang, Q., Jia, D. (2013). Evaluation of minimum quantity lubrication grinding with nano-particles and recent related patents, Recent Patents on Nanotechnology, Vol. 7, No. 2, 167-181, doi: 10.2174/187221051 13079990001.

[6] Padmini, R., Krishna, P.V., Rao, G.K.M. (2016). Effectiveness of vegetable oil based nanofluids as potential cutting fluids in turning AISI 1040 steel, Tribology International, Vol. 94, 490-501, doi: 10.1016/i.triboint.2015.10.006.

[7] Xuan, Y., Li Q. (2000). Heat transfer enhancement of nanofluids, International Journal of Heat and Fluid Flow, Vol. 21, No. 1, 58-64, doi: 10.1016/S0142-727X(99)00067-3.

[8] Lee, K., Hwang, Y., Cheong, S., Choi, Y., Kwon, L., Lee, J., Kim, S.H. (2009). Understanding the role of nanoparticles in nano-oil lubrication, Tribology Letters, Vol. 35, No. 2, 127-131, doi: 10.1007/s11249-009-9441-7. 
[9] Xia, Y., Ding, J., Ma, X., Yang, W. (1998). Study on test for improving the friction \& wear properties through adding metal power $\mathrm{nm}$ in diameter, Lubricating oil, No. 6, 37-40.

[10] Lee, P.-H., Nam, J.S., Li, C., Lee, S.W. (2012). An experimental study on micro-grinding process with nanofluid minimum quantity lubrication (MQL), International Journal of Precision Engineering and Manufacturing, Vol. 13, No. 3, 331-338, doi: 10.1007/s12541-012-0042-2.

[11] Wu, Y.Y., Tsui, W.C., Liu, T.C. (2007). Experimental analysis of tribological properties of lubricating oils with nanoparticle additives, Wear, Vol. 262, No. 7-8, 819-825, doi: 10.1016/i.wear.2006.08.021.

[12] Park, K.-H., Ewald, B., Kwon, P.Y. (2011). Effect of nano-enhanced lubricant in minimum quantity lubrication balling milling, Journal of Tribology, Vol. 133, No. 3, 1-8, doi: 10.1115/1.4004339.

[13] Shen, B., Kalita, P., Malshe, A.P., Shih, A.J. (2008). Performance of novel MoS2 nanoparticles based grinding fluids in minimum quantity lubrication grinding, In: Transactions of the North American Manufacturing Research Institution of SME, Vol. 36, 357-364.

[14] Nguyen, T.K., Do, I., Kwon, P. (2012). A tribological study of vegetable oil enhanced by nano-platelets and implication in MQL machining, International Journal of Precision Engineering and Manufacturing, Vol. 13, No. 7, 1077 1083, doi: 10.1007/s12541-012-0141-0.

[15] Li, Q., Xuan, Y. (2002). Convective heat transfer and flow characteristics of cu-water nanofluid, Science in China Series E: Technolgical Science, Vol. 45, No. 4, 408-416, doi: 10.3969/j.issn.1674-7321.2002.04.008.

[16] Liu, G., Li, X., Qin, B., Xing, D., Guo, Y., Fan, R. (2004). Investigation of the mending effect and mechanism of copper nano-particles on a tribologically stressed surface, Tribology Letters, Vol. 17, No. 4, 961-966, doi: 10.1007/ s11249-004-8109-6.

[17] Yan, J., Zhang, Z., Kuriyagawa, T. (2011). Effect of nanoparticle lubrication in diamond turning of reactionbonded SiC, International Journal of Automation Technology, Vol. 5, No. 3, 307-312, doi: 10.20965/ijat.2011. p0307.

[18] Sarıkaya, M., Güllü, A. (2014). Taguchi design and response surface methodology based analysis of machining parameters in CNC turning under MQL, Journal of Cleaner Production, Vol. 65, 604-616, doi: 10.1016/i.jclepro. 2013.08.040.

[19] Roy, R.K. (2010). A primer on the Taguchi method, 2nd edition, Society of Manufacturing Engineers, Michigan, USA.

[20] Yan, L., Yuan, S., Liu, Q. (2012). Influence of minimum quantity lubrication parameters on tool wear and surface roughness in milling of forged steel, Chinese Journal of Mechanical Engineering, Vol. 25, No. 3, 419-429, doi: 10.3901/CJME.2012.03.419.

[21] Maruda, R.W., Feldshtein, E., Legutko, S., Krolczyk, G.M. (2015). Research on emulsion mist generation in the conditions of minimum quantity cooling lubrication (MQCL), Tehnički vjesnik - Technical Gazette, Vol. 22, No. 5, 1213-1218, doi: $10.17559 /$ TV-20140423221850.

[22] Geng, G.S. (2006). Fundamental research on high speed milling of titanium alloys, PhD thesis, Nanjing University of Aeronautics and Astronautics, China.

[23] Jin, C., Chen, E., Wu, B. (2014). Analyzing for surface roughness in machining Ti-alloy by turn-milling, Tool Engineering, Vol. 48, No. 2, 74-76, doi: 10.3969/j.issn.1000-7008.2014.02.021.

[24] Zhou, C., Li, H. (2012). Surface roughness of high-speed milling TC21 titanium alloy, Aerospace Materials \& Technology, Vol. 42, No. 6, 105-108, doi: 10.3969/j.issn.1007-2330.2012.06.022.

[25] Li, F., Liu, W.-W., Wang, D.-F. (2015). Research on parameters optimization in milling of stainless steel based on Taguchi method, Aviation Precision Manufacturing Technology, Vol. 51, No. 6, 28-31, doi: 10.3969/j.issn.1003$\underline{5451.2015 .06 .007 .}$ 


\title{
Nov pristop z uporabo bakrenih nanodelcev pri mazanju z minimalnimi količinami pri rezkanju Ti-6Al-4V
}

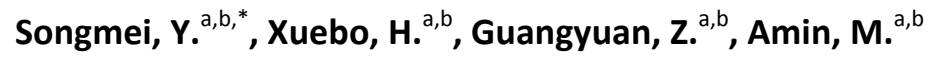 \\ ${ }^{a}$ Beihang University, School of Mechanical Engineering and Automation, Beijing, P.R. China \\ beijing Engineering Technological Research Center of High-efficient \& Green CNC Machining Process and Equipment, \\ Beijing, P.R. China
}

\begin{abstract}
POVZETEK
Dandanes se nanodelci dodajajo mazalnim sredstvom za izboljšanje mazalnih in hladilnih lastnosti. Na temo izboljšanja lastnosti strojnih obdelav z mazanjem z minimalnimi količinami (angl. MQL) z nanofluidi z dodanimi MoS2, $\mathrm{Al} 203$ in xGnP nanodelci je bilo narejenih več raziskav. Pomanjkanje raziskav je ugotovljeno na področju dodajanja kovinskih, npr. bakrenih nanodelcev. V tej raziskavi smo nanofluide pripravili z mešanjem štirih vrst nanodelcev $(\mathrm{Cu}$, grafit, MoS2 in Al203) v naravno-77 rastlinsko olje z dvema koncentracijama (1\% in $2 \%$ ). Za zasnovo eksperimenta smo uporabili pravokotno Taguchi matriko. Kakovost strojne obdelave je bila ovrednotena z zmanjšanjem rezalnih sil in površinske hrapavosti med MQL rezkanjem Ti-6Al-4V zlitine. Za določitev relativnega vpliva parametrov obdelave je izvedena analiza variance (ANOVA). Ugotovljeno je, da imata uporaba $\mathrm{Cu}$ in grafitnih nanodelcev največji vpliv na zmanjšanje rezalne sile in površinske hrapavosti. Rezultati ANOVA pokažejo, da tip in koncentracija nanodelcev odločilno vplivata na rezalno silo. Izvedeni testi za potrditev so pokazali, da $\mathrm{Cu}$ nanodelci znižajo rezalno silo za $8.84 \%$ in površinsko hrapavost za $14.74 \%$, grafitni nanodelci pa zmanjšajo rezalno silo za $5.51 \%$ in površinsko hrapavost za $21.96 \%$.
\end{abstract}

\section{PODATKI O ČLANKU}

Ključne besede:

Bakreni nanodelci

Mazanje z minimalnimi količinami (MQL)

Rezalna sila

Hrapavost površine

Analiza variance (ANOVA)

*Kontaktna oseba: yuansm@buaa.edu.cn (Songmei, Y.)

Zgodovina članka:

Prejet 16. januarja 2017

Popravljen 7. maja 2017

Sprejet 12. maja 2017 